\title{
Rhodolith Bed Discovered off the South African Coast
}

\author{
Luther A. Adams ${ }^{1, *}\left(\mathbb{D}\right.$, Gavin W. Maneveldt ${ }^{2}{ }^{(D}$, Andrew Green ${ }^{3}\left(\mathbb{D}\right.$, Natasha Karenyi ${ }^{1}$, \\ Denham Parker ${ }^{4,5}$, Toufiek Samaai ${ }^{4,5}$ and Sven Kerwath ${ }^{4,5}$ (D) \\ 1 Centre for Statistics in Ecology, Environment and Conservation, Department of Biological Sciences, \\ University of Cape Town, Rondebosch 7701, South Africa; natasha.karenyi@uct.ac.za \\ 2 Department of Biodiversity and Conservation Biology, University of the Western Cape, \\ Bellville 7535, South Africa; gmaneveldt@uwc.ac.za \\ 3 Geological Sciences, University of KwaZulu-Natal, Durban 3629, South Africa; greena1@ukzn.ac.za \\ 4 Department of Environment, Forestry and Fisheries, Cape Town 8001, South Africa; \\ denhamparker@gmail.com (D.P.); tsamaai@environment.gov.za (T.S.); svenk@daff.gov.za (S.K.) \\ 5 Department of Biological Sciences, University of Cape Town, Rondebosch 7701, South Africa \\ * Correspondence: admlut003@myuct.ac.za
}

Received: 27 February 2020; Accepted: 17 March 2020; Published: 27 March 2020

\begin{abstract}
Rhodolith beds have not previously been recorded in South Africa. A multidisciplinary research effort used remote sampling tools to survey the historically unexplored continental shelf off the Eastern Cape coast of South Africa. A rhodolith bed, bearing both living and dead non-geniculate coralline red algae, was discovered in the 30-65 m depth range off the Kei River mouth in the newly proclaimed Amathole Offshore Marine Protected Area. Some of the rhodolith forming coralline algal specimens were identified as belonging to at least three genera based on their morphology and anatomy, namely, Lithophyllum, Lithothamnion and a non-descript genus. Rhodolith mean mass and diameter were $44.85 \mathrm{~g} \pm 34.22 \mathrm{~g}$ and $41.28 \mathrm{~mm} \pm 10.67 \mathrm{~mm}(\mathrm{~N}=13)$, respectively. Remotely operated vehicle (ROV) imagery revealed a suite of epibenthic red macroalgae associated with the rhodolith bed. Taxonomy, vertical structure and distribution of rhodoliths in South Africa require further investigation.
\end{abstract}

Keywords: temperate mesophotic ecosystem; non-geniculate coralline algae; ROV

\section{Introduction}

Rhodoliths are live and dead aggregations of free-living non-geniculate coralline algae (Corallinales, Hapalidiales, Sporolithales: Corallinophycidae) from the phylum Rhodophyta [1]. They are important producers of calcium carbonate and are ecosystem engineers that support a high diversity of benthic fauna and algal communities [1-5]. Rhodolith beds have been documented to occur from the intertidal to $270 \mathrm{~m}$ depth [2,3] and constitute an important biogenic marine habitat worldwide. The community structure of rhodolith beds has been extensively studied in shelf environments prone to current agitation and sweeping, most notably in Brazil [6-9], but also in polar and subarctic seas [10,11], the Gulf of Mexico [12,13], the Mediterranean Sea [14-16] and southern Australia [17]. Rhodoliths are well known in the geological record and are useful indicators of palaeo-oceanographic conditions [18]. Rhodolith beds form habitats that represent an important transition between largely featureless, soft substrates and hard-cemented rocky reefs. Their three dimensional structure supports vast numbers of organisms from several different phyla [5,19], including polychaetes [20], barnacles [21], macroalgae [5,22] and molluscs [23]. Morphologically, rhodoliths are nodules consisting either of complete or fragmented layers of a single or multiple coralline algal species/thalli, all superimposed one on top of the other. "Boxwork" is the terminology for rhodoliths with a lattice structure and are made up of a nucleated core of either sand, rock or shell fragments [2,15]. Although found in the shallow subtidal in many 
parts of the world, their vertical (across depth) structure is understudied [3]. Even more so, little is known of the occurrence, community structure and ecology of rhodolith beds in South African waters, although occasional beach-clast rhodolith nodules have been recorded (e.g., Algoa Bay [21]). Here, we document the discovery of a mesophotic rhodolith bed off the South African coast in the 30-65 m depth range. The discovery was facilitated using multibeam echo sounder mapping, remotely operated vehicle (ROV) observations and dredge sampling. We also report on the identification of the rhodolith specimens, the morphology and associated epibionts of this rhodolith bed.

\section{Materials and Methods}

The studied localities are situated off the Eastern Cape coast of South Africa, offshore of the Kei River mouth in the newly proclaimed Amathole Offshore Marine protected Area (Figure 1). The continental shelf in the area is relatively narrow $(20 \mathrm{~km})$ and tapers to the north. The Agulhas Current, one of the strongest western-boundary currents in the world [24], flows along the shelf and together with a highly energetic wave regime [25] dominates the oceanographic conditions in this region. This is a warm temperate region which experiences the heaviest rainfall in January and February [26]. Fluvial input from the Kei River influences the adjacent coastal waters by lowering salinity and increasing turbidity [26].

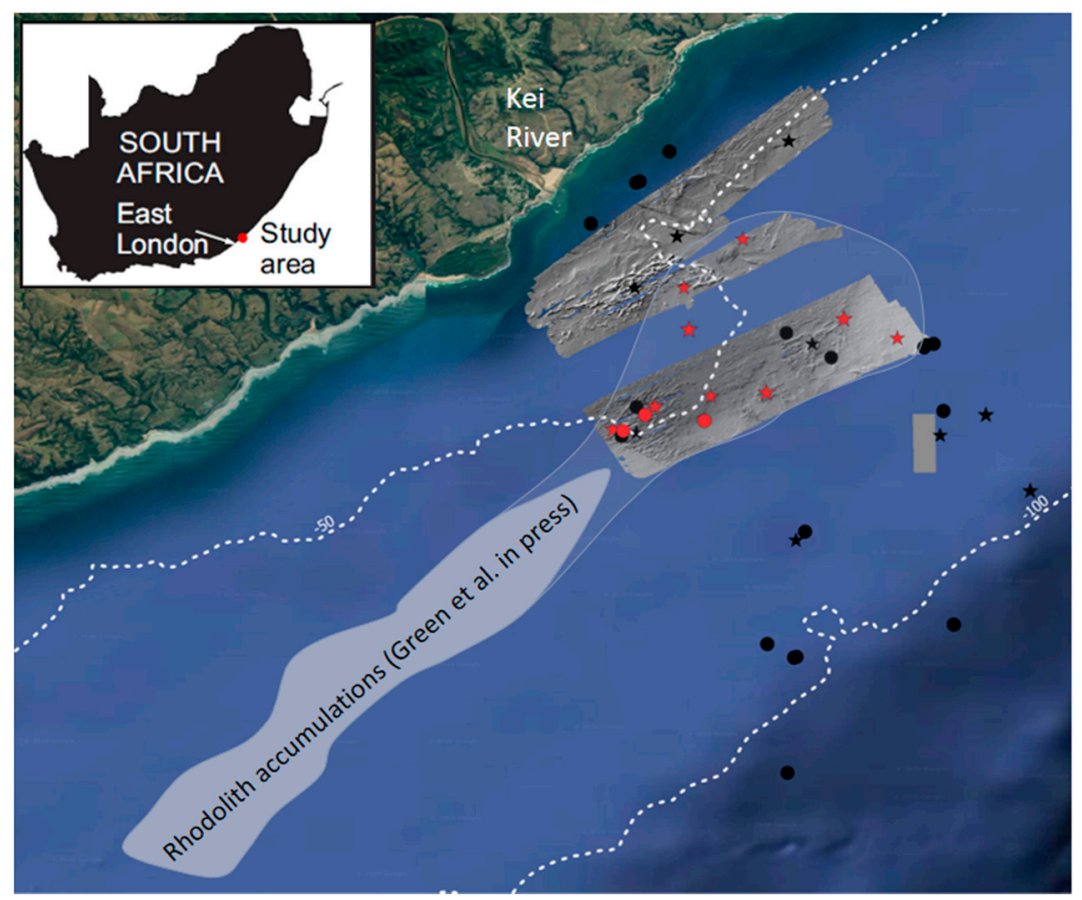

Figure 1. Speculated extent of rhodolith beds derived from seismic surveys (grey polygon), proposed extent of live rhodolith aggregations (light grey polygon) derived from remotely operated vehicle (ROV) surveys (red stars); dredge sampling (red circles) and multibeam bathymetry (greyscale relief) off the Kei River mouth, South Africa. Black stars and circles are ROV and dredge locations, respectively, which had no rhodoliths. The $50 \mathrm{~m}$ and $100 \mathrm{~m}$ isobaths are also depicted.

Surveys were conducted in 2016 and 2017 as part of the multidisciplinary and multi institutional African Coelacanth Ecosystem Programme (ACEP): Imida Frontiers Project. A Reson 7101 multibeam echo sounder, dredge sampler and remotely operated vehicle (ROV) were used to survey the continental shelf off the Kei River mouth. Multibeam bathymetry and backscatter data were collected in 2016 (see Green et al., submitted). Subsequently, dredge sampling and ROV surveys were used to ground truth the multibeam data and investigate the seafloor biology in January and May 2017. These visual surveys were conducted with the SAIAB SeaEye Falcon ROV aboard the RV Phakisa and performed at 
0.5 knots in the opposite direction of the current. Substratum type and epifauna were recorded for the epifaunal community analysis. Dredge samples were sorted and stored at $-80{ }^{\circ} \mathrm{C}$. During the Imida project $100 \mathrm{ROV}$ visual surveys were performed and 30 dredge samples collected in the 30-220 m and 25-214 m depth ranges respectively, between Kayser's Beach (-33.207 S, 27.613 E) and the Kei River mouth (-32.635 S, 28.429 E). Of these, only nine ROV visual surveys (30-65 m depth) and three dredge samples (45-57 m depth) revealed live rhodolith beds off the Kei River mouth (Figures 1 and 2). Rhodolith density was not measured because the seafloor area could not be accurately quantified.

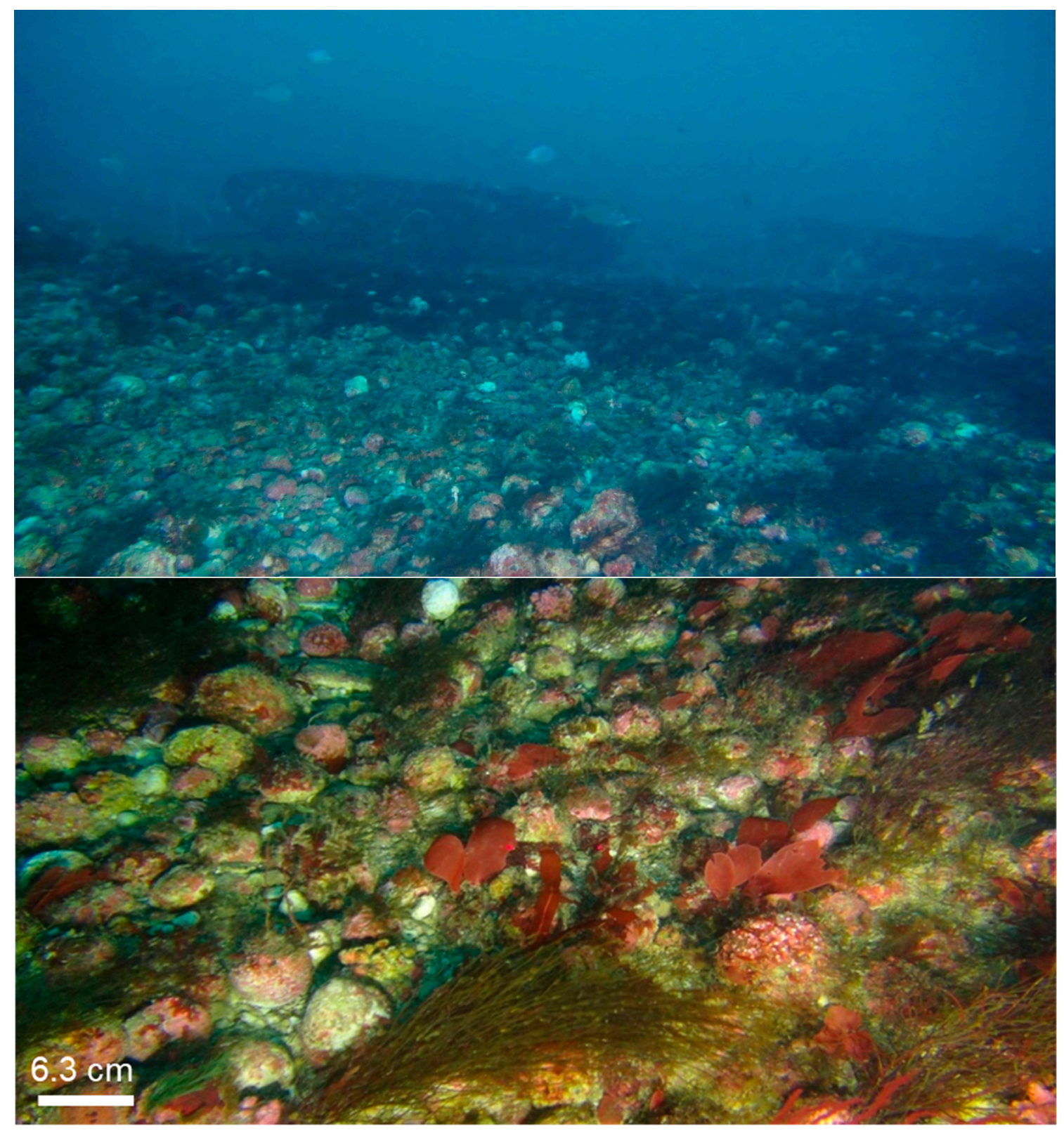

Figure 2. Remotely operated vehicle survey photographs collected during January/February 2017 of a rhodolith bed between 30 and $65 \mathrm{~m}$ depth off the Kei River mouth, South Africa.

A total of 13 individual rhodolith specimens (five from one and four each from another two dredge samples) were measured and classified for sphericity [27]. The degree of sphericity, estimated by measuring three diameters (largest, intermediate and smallest diameter) of each specimen utilising a digital calliper was graphically presented on a ternary plot for each of the three dredge sites. Largest individual diameter and wet mass were measured to estimate average size. Size measurements are 
presented as mean \pm standard deviation. A single rhodolith was also dated using the accelerator mass spectrometer (AMS) $\mathrm{C}^{14}$ method, where the centre-most and outer-most samples were examined for ages. Calibrated ages were calculated using the Southern Hemisphere atmospheric curve SHCal13 [28]. A reservoir correction (DeltaR) of $161 \pm 30$ was applied.

Epibiotic morphospecies obtained from ROV imagery were classified according to the CATAMI classification scheme due to the inherent difficulty with accurate genus or species level identification from underwater imagery (see Appendix A) [29]. Additionally, all epibionts found on the rhodolith specimens from dredge samples were removed and stored in $90 \%$ ethanol and identified to morphospecies or to the lowest operational taxonomic unit (OTU) using a dissection microscope.

Rhodolith specimens were prepared for light microscopy identification following Maneveldt et al. [30]. The outer layer of non-geniculate coralline algal specimens were tentatively identified to genus level based solely on their morphology and anatomy following the identification keys of Maneveldt et al. [31]. It was not possible to identify specimens to species level since many specimens were degraded and some had already fossilised, rendering identification through DNA sequencing costly and likely improbable. Additionally, the handling and storage protocols for the few remaining living specimens negated any successful molecular analyses.

\section{Results}

\subsection{Rhodolith Morphology and Age}

The average wet mass of the rhodoliths was $44.85 \mathrm{~g} \pm 34.22 \mathrm{~g}$. The average longest diameter of the specimens was $41.28 \mathrm{~mm} \pm 10.67 \mathrm{~mm}$. The largest rhodolith specimen had a wet mass of $107.2 \mathrm{~g}$ and a diameter of $63 \mathrm{~mm}$. Spheroidal forms included compact, compact-bladed and compact elongated (Figures 3 and 4). Cross-sections of several specimens revealed a "boxwork" structure (e.g., Figure 5). AMS $C^{14}$ analyses revealed that the rhodoliths started forming between 7406 and $7225 \mathrm{cal} \mathrm{yr}$. BP. The outer part of the rhodoliths dated to $150 \mathrm{cal}$ yr. BP to post-bomb, indicating contemporary growth.
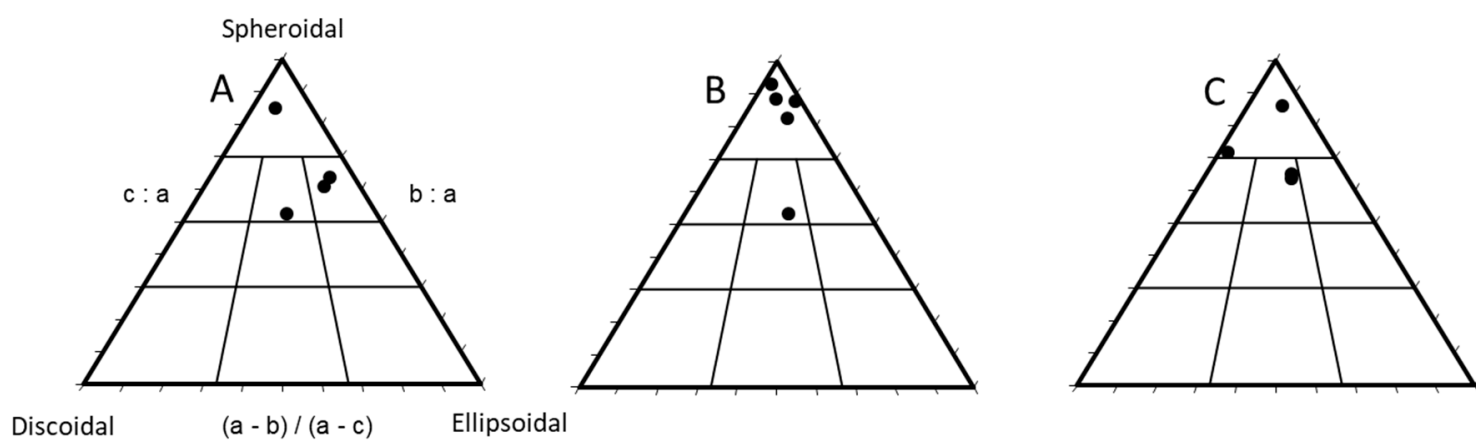

Figure 3. Degree of sphericity of the rhodoliths from the three dredge sites $(\mathbf{A}-\mathbf{C})$ off the Kei River mouth, South Africa ( $n=4$ per site). 


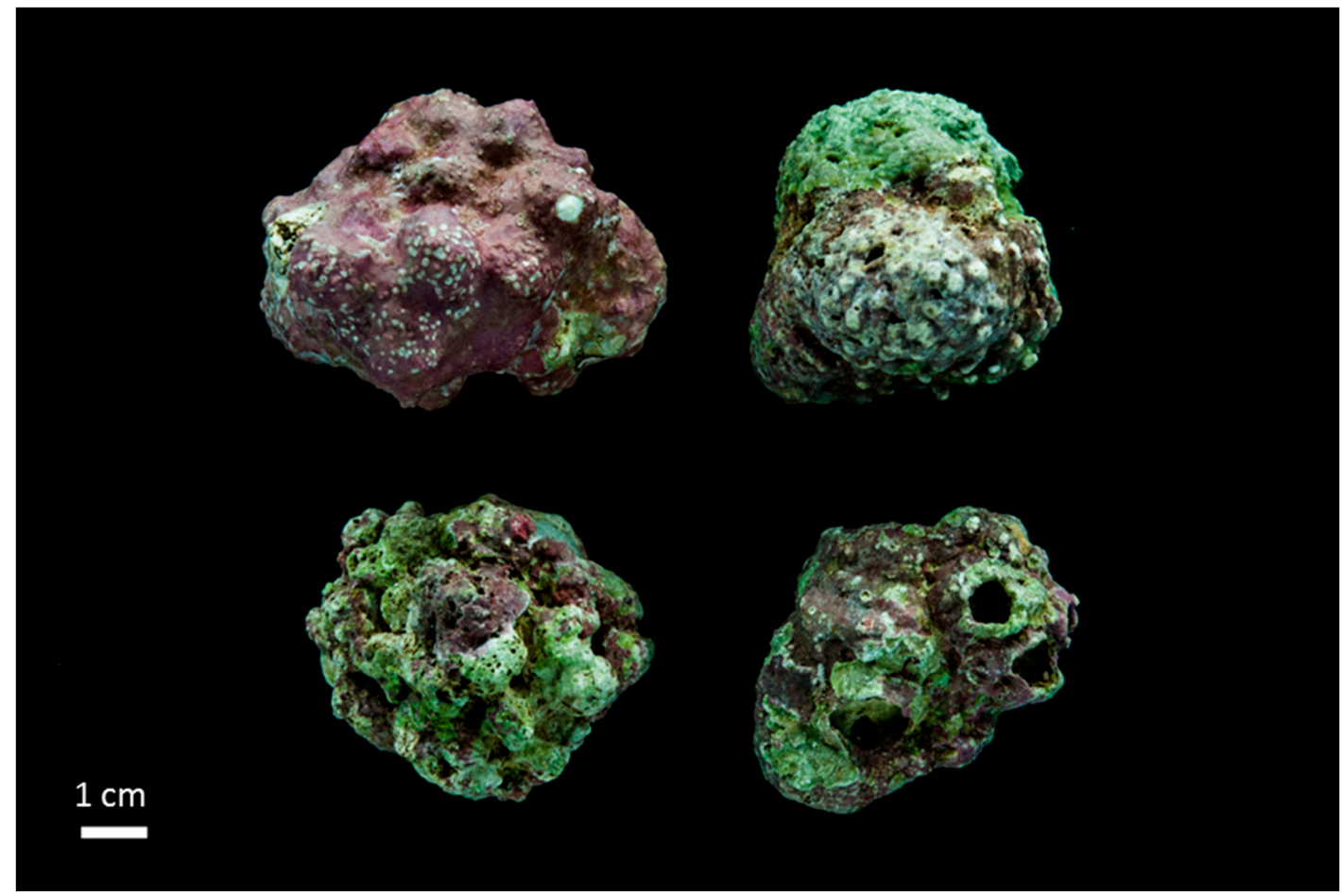

Figure 4. High resolution photographs of the rhodoliths collected by dredge sampling from $40 \mathrm{~m}$ depth off the Kei River mouth, South Africa.

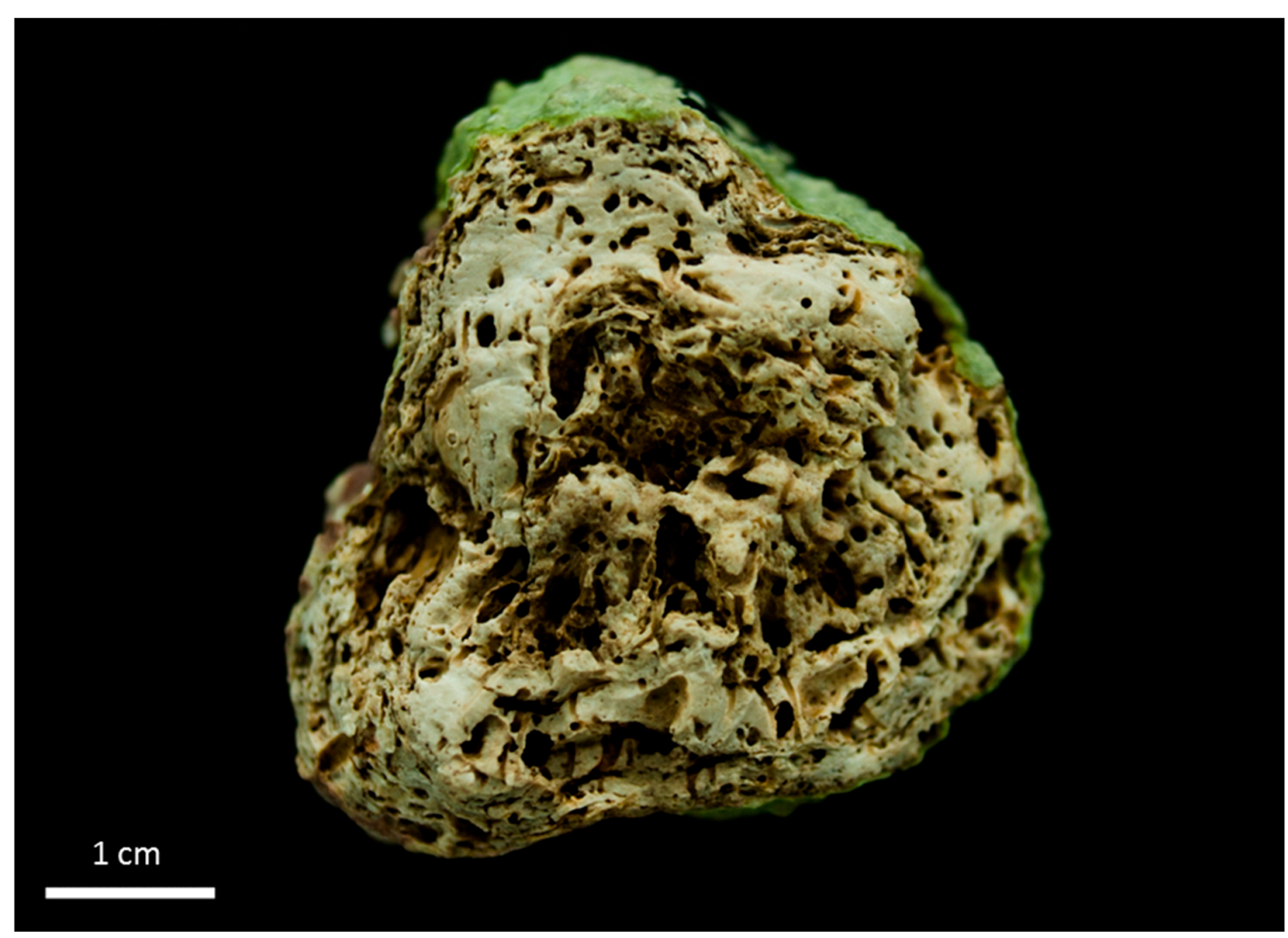

Figure 5. Cross-section of a rhodolith displaying the "boxwork" structure.

\subsection{Depositional Setting and Epibiotic Components}

ROV and multibeam imagery revealed that the rhodolith bed occupied low relief areas on course siliclastic and bioclastic sediment (Figure 6). Rhodolith beds were also observed in inter-reef 
spaces. Surge and current (in excess of 3 knots) were strong. Multibeam and backscatter imagery also indicated current sweeping and wave agitation of the seafloor where rhodoliths occur (Figure 6). Coast-parallel, bifurcating and symmetrical large wave-formed dunes (of $20 \mathrm{~cm}$ amplitude, 9-10 m wavelength) co-occurred with rhodolith beds (Figure 6A) and were bordered along the coastal strike by several coast-elongate gravel ribbons orientated with the Agulhas Current (Figure 6B). Sand streamers and current-reworked wave-formed dunes characterised shallower $(<36 \mathrm{~m})$ rhodolith occurrences (Figure 6C). Bleached (dead) rhodolith specimens were common throughout the observed depth range which indicated natural mortalities, likely because of occasional sand burial due to disturbance caused by wave action and strong currents. The close association of current-sweeping seafloor features with living and bleached rhodoliths suggests that the current agitation causes frequent rolling/turnover of individuals to reveal the dead underside. ROV imagery revealed a diversity of upright fleshy macroalgae which was the most common morphospecies type observed besides the rhodolith forming non-geniculate coralline algae. Although a diverse assemblage of fleshy macroalgae was observed in the ROV imagery, only a single turf alga Dascoclonium palmatifidum was found attached to a single rhodolith specimen. Microscopy of the associated epifauna revealed two cryptic sponges, a bristle worm, two bryozoan colonies, a clamshell and polychaete tubes.

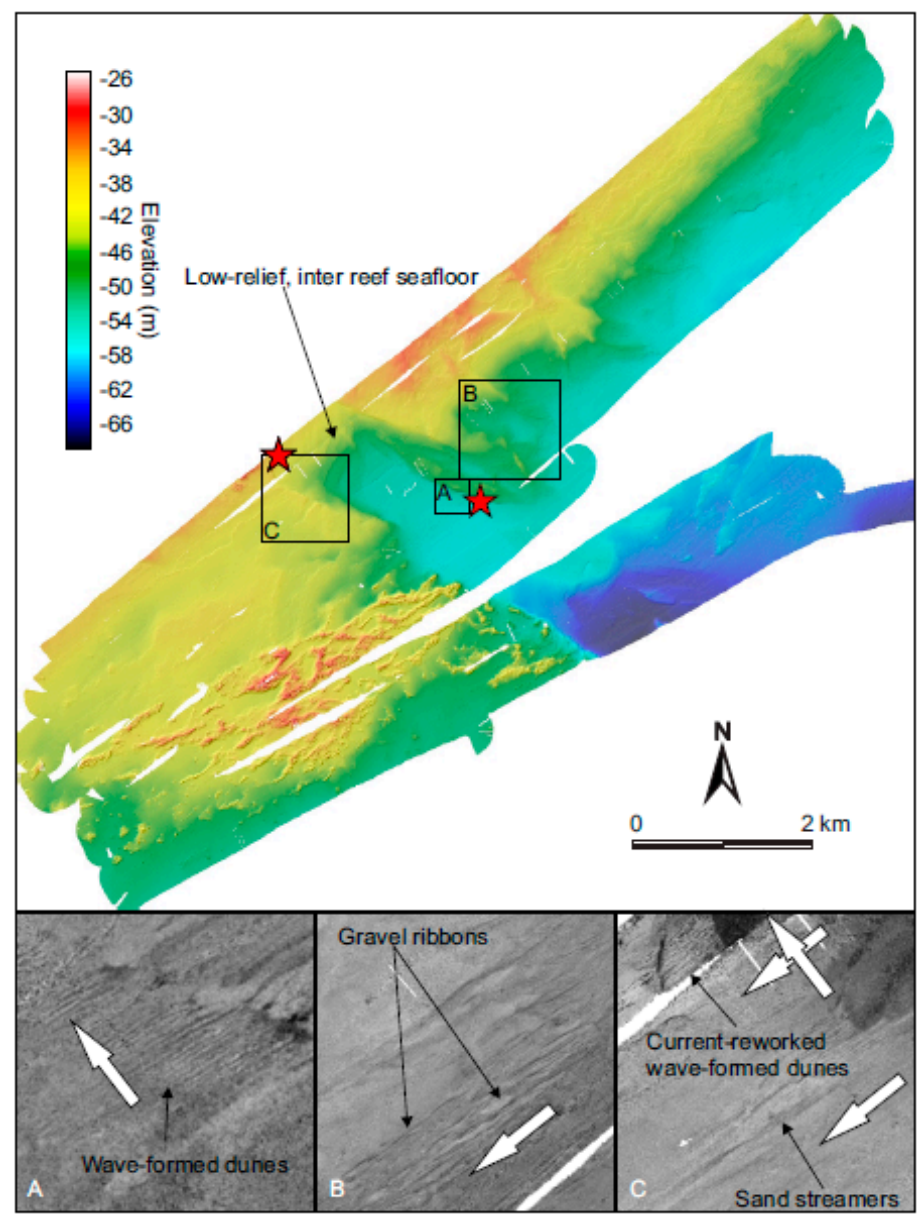

Figure 6. Multibeam image of the mid-shelf offshore the Kei River mouth. Red stars denote rhodoliths observed from ROV surveys. Note the association with low relief, inter reef areas. Insets depict select areas of seafloor backscatter data (dark-high, light-low), with current direction denoted by white arrows. A, Coast-parallel, wave-formed dunes. B, Coast-elongate, high backscatter ribbons denoting gravel streamers formed by the Agulhas current. C, Top of inset shows wave-formed dunes, broken down and reworked by coast-parallel flows. Bottom shows elongate, coast-parallel stripes of moderate backscatter interpreted as sand streamers formed in the Agulhas current. 


\subsection{Non-geniculate Coralline Algal Identifications}

The non-geniculate coralline algae that comprised the outermost superimposed layer of the rhodoliths included taxa from at least two of three known coralline algal orders (namely Corallinales and Hapalidiales), including several specimens from the genera Lithophyllum and Lithothamnion and one non-descript taxon from neither of these genera (Figure 7).

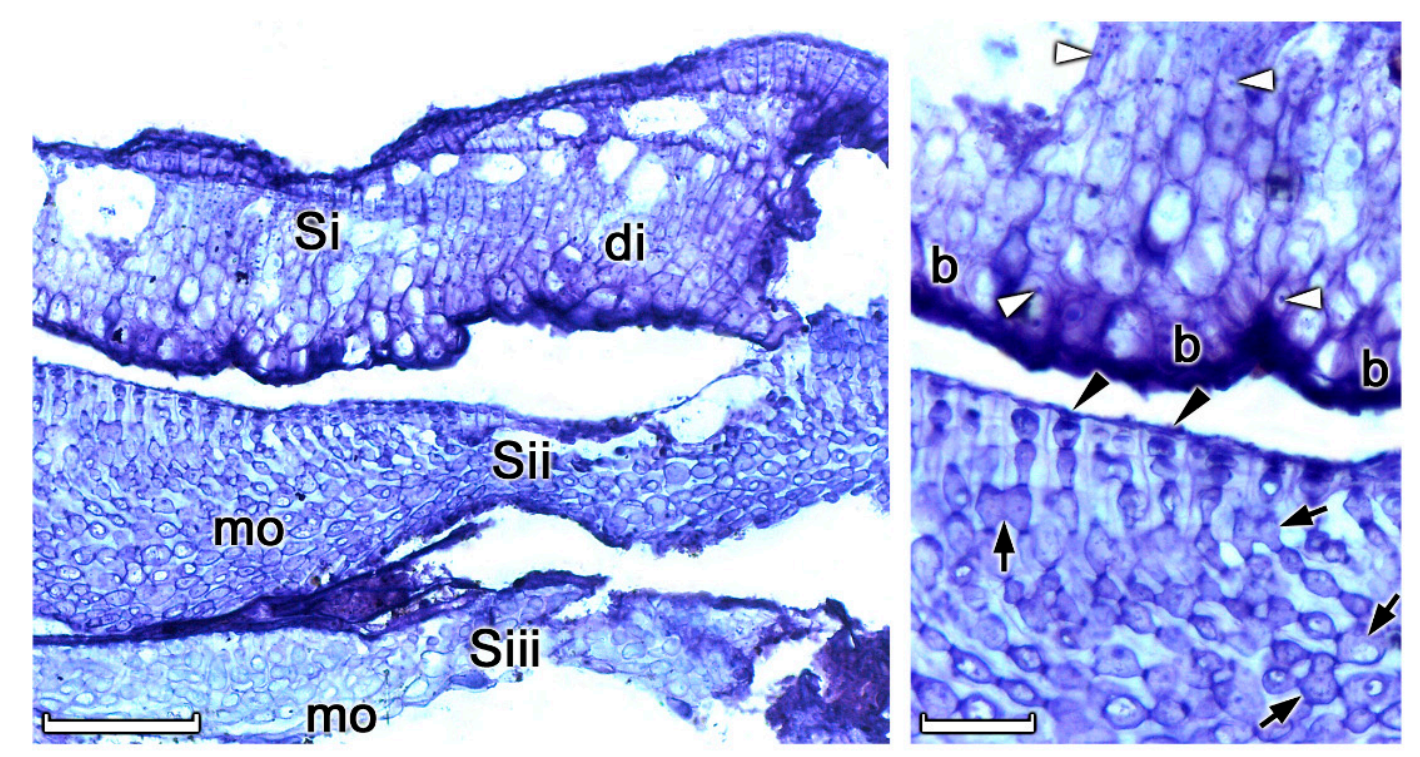

Figure 7. (Left and right) Three different living species growing in a superimposed manner (Si-Siii) on a single rhodolith (sample 15E). The outer crust (Si) belonging to the genus Lithophyllum had a dimerous thallus construction (di) with a single basal layer (b) of non-palisade cells and with secondary pit connections (white arrowheads) between cells of adjacent filaments. The middle crust (Sii) belonging to the genus Lithothamnion with senescent multiporate conceptacles (not evident in these images) had a monomerous thallus construction (mo), flared epithallial cells (black arrowheads) and cell fusions (black arrows) between cells of adjacent filaments. The inner crust (Siii) was non-descript, although it possessed a monomerous thallus construction, rounded epithallial cells and cell fusions between cells of adjacent filaments. Scale bars: $100 \mu \mathrm{m}$ (left); $20 \mu \mathrm{m}$ (right).

\section{Discussion}

The persistence of this rhodolith bed may be attributed to the physical properties, the strength of the Agulhas current and to some extent the strong wave climate that may impinge on the seafloor at depths of $<65 \mathrm{~m}$. This is despite its occurrence offshore of the Kei River mouth, a source of high sediment loads to the shelf (Green et al., submitted). The strength of the wave agitation, coupled with the vigorous Agulhas current, may promote the persistent exposure and reworking of the rhodolith bed by suppressing the settlement of fine sand and particulate organic matter that would otherwise smother the rhodoliths and cause die-offs [32]. Sparse aggregations of dead rhodoliths, covered or partially covered in particulate organic matter and silt, were found on the fringes of the bed, which suggests that settlement of fluvial sediment from the Kei River influences the extent of the rhodolith bed. Furthermore, we postulate that the extent of the bed is dynamic due to strong bed-traction currents shifting sediments. Especially in the mid-shelf where sediment accumulation becomes more prominent, mobile bedform fields can migrate over gravel or bedrock areas typically exposed at the seafloor [33].

Fluvial influence from the Kei River may also limit the landward extent of the rhodolith bed. Besides irradiance (which is a function of depth and turbidity) being the major control of depth distribution $[3,34]$, most species of coralline algae cannot tolerate extreme temperature and salinity fluctuations [9,10], phenomena that are experienced off the Kei River mouth. During January to 
February of each year, this region experiences its highest rainfall [26], which increases freshwater input that dramatically reduces salinity. Additionally, the coastline experiences localised upwelling caused by a current-driven cyclonic eddy which in turn brings cold, subsurface, nutrient enriched deep water onto the otherwise oligotrophic warm shelf [26]. This phenomenon, however, is not uncommon and despite temperature and salinity fluctuations being a limiting factor to their distribution, several species of non-geniculate coralline algae (notably from the genera Lithothamnion and Lithophyllum) are known to tolerate extreme fluctuations in temperature and salinity levels, for example off the Amazon River [9], in Norway [10], in Italy [16] and in northern Ireland [32]. The joint influence of these events on the underlying Kei River mouth rhodolith community is not understood and further investigation into the ecological controls is needed. Furthermore, identifying the species of rhodolith off the Kei River could possibly bring to light the mechanisms, for example, low light adaptation, fluctuating salinity and temperature tolerance by which this bed may have persisted in these volatile conditions. In this regard, more directed sampling for molecular analyses should be attempted in future.

The average size of the rhodoliths was $41 \mathrm{~mm}$, which is comparatively smaller than the global average of $60 \mathrm{~mm}$ [2]. Assuming that the rhodolith with a diameter of $43 \mathrm{~mm}$ continuously accumulated all its material over a roughly 7255 year period, the accumulation rate may be calculated at 0.0059 mm.yr. ${ }^{-1}$. Compared to rhodoliths comprising Mesophyllum crassiusculum (as Lithothamnium crassiusculum, $0.6 \mathrm{~mm} . \mathrm{yr}^{-1}{ }^{-1}$ [35]) from similar climatic zones, this rate is almost two orders of magnitude slower. Branch growth rates of free living, branching coralline algae that form rhodoliths vary from

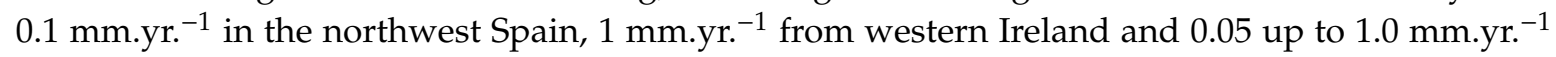
in Norway [36]. Thick (0.5-1 m) aggregate deposits of rhodoliths appear to accumulate slower [36], and at rates comparable to the Eastern Cape rhodoliths, for example $0.5 \mathrm{~m} . \mathrm{ky}^{-1}$ in Cornwall, 1.4 $\mathrm{m} . \mathrm{ky}^{-1}$ from raised rhodolith deposits in Norway and the very slow $0.08 \mathrm{~m} . \mathrm{ky}^{-1}$ from Orkney sounds in Northern Scotland [36]. Like the thicker deposits, the Eastern Cape rhodoliths clearly comprise aggregate features consisting of older cores around which more recent, opportunistic (most specimens were thin and non-fertile, pers. obs.) living non-geniculate coralline algae have accumulated (see for example Goldberg et al. [17]). According to Cooper et al. [37], sea level occupied a position $0.5 \mathrm{~m}$ above present day mean sea level 7200 years ago. At this point, the shelf was drowned by the ocean, and full current-sweeping between depths of 40 and $60 \mathrm{~m}$ probably took place. It is unclear where the hiatus in accumulation occurs, however, the chipping and abrasion observed from contemporary rhodolith specimens suggest that the entire accumulation process was a punctuated one, with multiple hiatuses related to the high energy conditions. We thus postulate that on such a high energy, wave and current dominated environment, overall rhodolith accumulation would be slow mainly due to the highly energetic water column. The large rhodoliths observed in this study (63 mm diameter) probably represent a threshold growth point for most species in this environment. Additionally, these larger rhodoliths appeared to be the stratified accumulations of corallines and fine sediments (pers. obs.), which have characteristically been seen in other locations prone to high sediment loading [38].

The spheroidal rhodolith shape found off the Kei River mouth concurs with rhodolith shapes found elsewhere in high energy environments $[7,16,37]$. Surge and wave action were common at all rhodolith sites and "white" (bleached, dead) rhodoliths were a common feature at all sites (pers. obs.). The constant disturbance probably results in regular rolling and turnover of rhodoliths, which then promote the spheroidal morphology [16,37]. Bioeroders are also known to influence the shape and structure of rhodoliths [39]. Moreover, grazers (e.g., chitons and herbivorous fish) and bioeroders (sponges, barnacles and polychaetes) also facilitate the growth of rhodoliths by preventing the settlement and overgrowth of the rhodoliths by sessile epiphytes that compete for essential light, nutrients and space $[19,40]$. Besides providing food and shelter for benthic grazers, rhodoliths, especially larger ones, provide shelter and spawning substrates for fish $[9,11]$.

Rhodoliths, hollow and nucleated, are known to increase habitat complexity and biodiversity by offering increased surface area for the attachment of epibionts such as other forms of macroalgae [5], as well as shelter and egg deposition sites for benthic fauna [39]. Interestingly, of the 13 dredge 
specimens collected, only four were hollow (i.e., not nucleated) or possessed cavities large enough for small organisms $(<1 \mathrm{~cm}$ in diameter) to persist whereas solid rhodoliths did not possess cavities. Moreover, several rhodoliths possessed a network of polychaete burrows right down to the core. Several studies $[39,41,42]$ have suggested that boring bivalves are important bioeroders that facilitate rhodolith hole production. A recent study recorded the burrowing barnacle Weltneria spinosa from beach-cast rhodolith specimens $280 \mathrm{~km}$ south of this study area in Algoa Bay, South Africa [21]. These beach-casts were comprised of at least two species of rhodolith forming non-geniculate coralline algae, one of which incidentally also belonged to the genus Lithophyllum. This finding, along with the findings from the current study, not only highlights the poor sampling coverage of the shallow subtidal benthic environment along the Eastern Cape coast but also demonstrates how very little we know of their identification, the distribution of rhodoliths or their depth range along this and other stretches of the South African coastline.

\section{Conclusions}

Here we highlight the discovery, the geographical extent, rhodolith morphology and the associated rhodolith epibionts of a rhodolith bed off the South African east coast. The persistence of rhodolith fields on the Eastern Cape shelf appears to be related to dynamic bed shearing by currents and is limited by fluvial sediment inundation in the inner shelf and cold-water upwelling along the shelf edge. The rhodoliths mark the inception of the Agulhas Current's sweeping of the shelf approximately 7200 years ago and has episodically accreted since. The slow growth rates are unlike those in most other studies and point to the episodic high energy regime limiting the size and rate at which these rhodoliths may grow to, likely due to alternating phases of abrasion and stasis. Their size and shape are also strongly controlled by bioeroders, which in the South African context are still poorly understood. With the recent increase in offshore visual surveys and increased accessibility to remote camera platforms as research tools, we are likely to see more discoveries of rhodolith beds within the South African Exclusive Economic Zone and more focussed research into the ecological, biological and geological significance of these important marine habitats. Incidentally this study area falls within the newly proclaimed Amathole Offshore Marine Protected Area, which ensures the protection of this feature. We recommend a finer scale study of the taxonomy, morphology, ecology and geography of the rhodolith bed off the Kei River mouth.

Author Contributions: Conceptualisation, D.P., N.K. and L.A.A.; methodology, L.A.A., A.G. and G.W.M.; software, A.G.; formal analysis, A.G., G.W.M. and L.A.A.; data curation, T.S., G.W.M.; writing-original draft preparation, L.A.A.; writing-review and editing, A.G., N.K., D.P., S.K., G.W.M. and L.A.A.; visualisation, L.A.A.; supervision, N.K. and D.P.; project administration, S.K.; funding acquisition, S.K. All authors have read and agreed to the published version of the manuscript.

Funding: This research was funded by the DST/NRF African Coelacanth Ecosystem Programme (ACEP), grant number 97969.

Acknowledgments: We would like our to thank Kerry Sink for facilitating ROV expeditions; the SAIAB team; ROV pilot Ryan Palmer; crew members of the RV Phakisa, Nick Riddin, Siseko Benya, Thor Eriksen and Koos Smith, who facilitated with the collection of ROV imagery and dredge sample collections; Robyn Payne, for sorting and cataloguing the dredge specimens; Maggie Reddy and John Bolton, for the turf alga identification; Erin Adams, for assistance with histological processing; and the National Research Foundation and the Department of Environment, Forestry and Fisheries for funding.

Conflicts of Interest: The authors declare no conflict of interest. 


\section{Appendix A}

Table A1. List of rhodolith associated epibionts found off the Kei River, South Africa, identified according to the CATAMI classification scheme.

\begin{tabular}{cc}
\hline Morphospecies Code & Morphospecies Name \\
\hline ASS & Solitary stalked ascidian \\
AUC & Colonial unstalked ascidians \\
AUS & Solitary unstalked ascidians \\
CB & Black and Octocorals \\
CBBFA & Fleshy arborescent octocorals \\
CBBFM & Fleshy mushroom octocorals \\
CBFR & 2D rigid fan octocorals \\
CBW & Whip corals \\
CNHYD & Hydroids \\
EF & Feather stars \\
EOBSS & Brittle stars \\
MAA & Articulate calcareous macroalgae \\
MAAR & Articulate calcareous red macroalgae \\
MAECR & Erect course branching red macroalgae \\
MAEFR & Erect fine branching red macroalgae \\
MAENR & Encrusting red macroalgae \\
MAENRC & Encrusting red calcareous macroalgae \\
MAENRNC & Encrusting red non-calcareous macroalgae \\
MAF & Filamentous macroalgae \\
MAFR & Filamentous red macroalgae \\
MALAR & Laminate red macroalgae \\
MASR & Sheet-like red macroalgae \\
MAEN & Encrusting macroalgae \\
MOB & Bivalves \\
SPCE & Creeping/ramose sponges \\
SPES & Simple erect sponges \\
SPM & Massive sponges \\
\hline &
\end{tabular}

\section{References}

1. Riosmena-Rodríguez, R.; Nelson, W.; Aguirre, J. Rhodolith/maërl Beds: A Global Perspective; Springer International Publishing: Basel, Switzerland, 2017.

2. Foster, M.S. Rhodoliths: Between rocks and soft places. J. Phycol. 2001, 37, 659-667. [CrossRef]

3. Foster, M.S.; Amado Filho, G.M.; Kamenos, N.A.; Riosmena-Rodriguez, R.; Steller, D.L. Rhodoliths and rhodolith beds. Smithson. Contrib. Mar. Sci. 2013, 39, 143-155.

4. Steller, D.L.; Foster, M.S. Environmental factors influencing distribution and morphology of rhodoliths in Bahía Concepción, B.C.S., México. J. Exp. Mar. Bio. Ecol. 1995, 194, 201-212. [CrossRef]

5. Amado-Filho, G.; Maneveldt, G.; Pereira-Filho, G.; Manso, R.; Bahia, R.; Barros-Barreto, M.; Guimarães, S.M.P.B. Seaweed diversity associated with a Brazilian tropical rhodolith bed. Ciencias Mar. 2010, 36, 371-391. [CrossRef]

6. Vale, N.F.; Amado-Filho, G.M.; Braga, J.C.; Brasileiro, P.S.; Karez, C.S.; Moraes, F.C.; Bahia, R.G.; Bastos, A.C.; Moura, R.L. Structure and composition of rhodoliths from the Amazon River mouth, Brazil. J. South Am. Earth Sci. 2018, 84, 149-159. [CrossRef]

7. Amado-Filho, G.M.; Maneveldt, G.; Manso, R.C.C.; Marins-Rosa, B.V.; Pacheco, M.R.; Guimarães, S.M.P.B. Estructura de los mantos de rodolitos de 4 a 55 metros de profundidad en la costa sur del estado de Espírito Santo, Brazil. Ciencias Mar. 2007, 33, 399-410. [CrossRef]

8. Bahia, R.G.; Abrantes, D.P.; Brasileiro, P.S.; Pereira Filho, G.H.; Amado Filho, G.M. Rhodolith bed structure along a depth gradient on the northern coast of Bahia state, Brazil. Brazilian J. Oceanogr. 2010, 58, 323-337. [CrossRef] 
9. Villas-Boas, A.B.; Riosmena-Rodriguez, R.; de Oliveira Figueiredo, M.A. Community structure of rhodolith-forming beds on the central Brazilian continental shelf. Helgol. Mar. Res. 2014, 68, 27-35. [CrossRef]

10. Teichert, S.; Woelkerling, W.; Rüggeberg, A.; Wisshak, M.; Piepenburg, D.; Meyerhöfer, M.; Form, A.; Freiwald, A. Arctic rhodolith beds and their environmental controls (Spitsbergen, Norway). Facies 2014, 60, 15-37. [CrossRef]

11. Gagnon, P.; Matheson, K.; Stapleton, M. Variation in rhodolith morphology and biogenic potential of newly discovered rhodolith beds in Newfoundland and Labrador (Canada). Bot. Mar. 2012, 55, 85-99. [CrossRef]

12. Hetzinger, S.; Halfar, J.; Riegl, B.; Godinez, L. Sedimentology and Acoustic Mapping of Modern Rhodolith Facies on a Non- Tropical Carbonate Shelf (Gulf of California, Mexico). J. Sediment. Res. 2006, 76, 670-682. [CrossRef]

13. Fredericq, S.; Arakaki, N.; Camacho, O.; Gabriel, D.; Krayesky, D.; Self-Krayesky, S.; Rees, G.; Richards, J.; Sauvage, T.; Venera-Ponton, D.; et al. A Dynamic Approach to the Study of Rhodoliths: A Case Study for the Northwestern Gulf of Mexico. Cryptogam. Algol. 2014, 35, 77-98. [CrossRef]

14. Rindi, F.; Braga, J.C.; Martin, S.; Peña, V.; Le Gall, L.; Caragnano, A.; Aguirre, J. Coralline Algae in a Changing Mediterranean Sea: How Can We Predict Their Future, if We Do Not Know Their Present? Front. Mar. Sci. 2019, 6, 723. [CrossRef]

15. Basso, D. Deep rhodolith distribution in the Pontian Islands, Italy: A model for the paleoecology of a temperate sea. Palaeogeogr. Palaeoclimatol. Palaeoecol. 1998, 137, 173-187. [CrossRef]

16. Sañé, E.; Chiocci, F.L.; Basso, D.; Martorelli, E. Environmental factors controlling the distribution of rhodoliths: An integrated study based on seafloor sampling, ROV and side scan sonar data, offshore the W-Pontine Archipelago. Cont. Shelf Res. 2016, 129, 10-22. [CrossRef]

17. Goldberg, N. Age estimates and description of rhodoliths from Esperance Bay, Western Australia. J. Mar. Biol. Assoc. U.K. 2006, 86, 1291-1296. [CrossRef]

18. Bassi, D.; Nebelsick, J.H.; Checconi, A.; Hohenegger, J.; Iryu, Y. Present-day and fossil rhodolith pavements compared: Their potential for analysing shallow-water carbonate deposits. Sediment. Geol. 2009, 214, 74-84. [CrossRef]

19. Steller, D.L.; Riosmena-Rodríguez, R.; Foster, M.S.; Roberts, C.A. Rhodolith bed diversity in the Gulf of California: The importance of rhodolith structure and consequences of disturbance. Aquat. Conserv. Mar. Freshw. Ecosyst. 2003, 13, 5-20. [CrossRef]

20. Berlandi, R.M.; de O. Figueiredo, M.A.; Paiva, P.C. Rhodolith Morphology and the Diversity of Polychaetes Off the Southeastern Brazilian Coast. J. Coast. Res. 2012, 279, 280-287. [CrossRef]

21. Botha, T.P.A.; Griffiths, C.L.; Maneveldt, G.W. Coralline red algae - a new host taxon for burrowing barnacles (Cirripedia, Acrothoracica). Mar. Biodivers. 2020, 50, 1-5. [CrossRef]

22. Pascelli, C.; Riul, P.; Riosmena-rodríguez, R.; Scherner, F.; Nunes, M.; Hall-spencer, J.M.; Cabral, E.; Oliveira, D.; Horta, P. Seasonal and depth-driven changes in rhodolith bed structure and associated macroalgae off Arvoredo island ( southeastern Brazil ). Aquat. Bot. 2013, 111, 62-65. [CrossRef]

23. Steller, D.L.; Cáceres-Martínez, C. Coralline algal rhodoliths enhance larval settlement and early growth of the pacific calico scallop Argopecten ventricosus. Mar. Ecol. Prog. Ser. 2009, 396, 49-60. [CrossRef]

24. Roberts, M.J.; van der Lingen, C.D.; Whittle, C.; van den Berg, M. Shelf currents, lee-trapped and transient eddies on the inshore boundary of the agulhas current, South Africa: Their relevance to the kwaZulu-Natal sardine run. African J. Mar. Sci. 2010, 32, 423-447. [CrossRef]

25. Dixon, S.; Green, A.; Cooper, A. Storm Swash Deposition On An Embayed Rock Coastline: Facies, Formative Mechanisms, and Preservation. J. Sediment. Res. 2015, 85, 1155-1165. [CrossRef]

26. Russo, C.S.; Lamont, T.; Tutt, G.C.O.; van den Berg, M.A.; Barlow, R.G. Hydrography of a shelf ecosystem inshore of a major Western Boundary Current. Estuar. Coast. Shelf Sci. 2019, 228, 106363. [CrossRef]

27. Sneed, E.D.; Folk, R.L. Pebbles in the Lower Colorado River, Texas a Study in Particle Morphogenesis. J. Geol. 1958, 66, 114-150. [CrossRef]

28. Hogg, A.G.; Hua, Q.; Blackwell, P.G.; Niu, M.; Buck, C.E.; Guilderson, T.P.; Heaton, T.J.; Palmer, J.G.; Reimer, P.J.; Reimer, R.W.; et al. SHCal13 Southern Hemisphere Calibration, 0-50,000 Years cal BP. Radiocarbon 2013, 55, 1889-1903. [CrossRef] 
29. Althaus, F.; Hill, N.; Ferrari, R.; Edwards, L.; Przeslawski, R.; Schönberg, C.H.L.; Stuart-Smith, R.; Barrett, N.; Edgar, G.; Colquhoun, J.; et al. A standardised vocabulary for identifying benthic biota and substrata from underwater imagery: The CATAMI classification scheme. PLOS ONE 2015, 10, e0141039. [CrossRef]

30. Maneveldt, G.W.; van der Merwe, E. Heydrichia cerasina sp. nov. (Sporolithales, Corallinophycidae, Rhodophyta) from the southernmost tip of Africa. Phycologia 2012, 51, 11-21. [CrossRef]

31. Maneveldt, G.W.; Van der Merwe, E.; Keats, D.W. Updated keys to the non-geniculate coralline red algae (Corallinophycidae, Rhodophyta) of South Africa. South African J. Bot. 2016, 106, 158-164. [CrossRef]

32. Wilson, S.; Blake, C.; Berges, J.A.; Maggs, C.A. Environmental tolerances of free-living coralline algae (maerl): Implications for European marine conservation. Biol. Conserv. 2004, 120, 279-289. [CrossRef]

33. Flemming, B.W. Sand transport and bedform patterns on the continental shelf between Durban and Port Elizabeth (southeast African continental margin). Sediment. Geol. 1980, 26, 179-205. [CrossRef]

34. Figueiredo, M.A.O.; Coutinho, R.; Villas-Boas, A.B.; Tâmega, F.T.S.; Mariath, R. Deep-water rhodolith productivity and growth in the southwestern Atlantic. J. Appl. Phycol. 2012, 24, 487-493. [CrossRef]

35. Frantz, B.R.; Kashgarian, M.; Coale, K.H.; Foster, M.S. Growth rate and potential climate record from a rhodolith using 14C accelerator mass spectrometry. Limnol. Oceanogr. 2000, 45, 1773-1777. [CrossRef]

36. Bosence, D.; Wilson, J. Maerl growth, carbonate production rates and accumulation rates in the northeast Atlantic. Aquat. Conserv. Mar. Freshw. Ecosyst. 2003, 13, 21-31. [CrossRef]

37. Cooper, J.A.G.; Green, A.N.; Compton, J.S. Sea-level change in southern Africa since the Last Glacial Maximum. Quat. Sci. Rev. 2018, 201, 303-318. [CrossRef]

38. Holz, V.L.; Bahia, R.G.; Karez, C.S.; Vieira, F.V.; Moraes, F.C.; Vale, N.F.; Sudatti, D.B.; Salgado, L.T.; Moura, R.L.; Amado-filho, G.M.; et al. Structure of Rhodolith Beds and Surrounding Habitats at the Doce River Shelf (Brazil). Diversity 2020, 12, 75. [CrossRef]

39. Teichert, S. Hollow rhodoliths increase Svalbard's shelf biodiversity. Sci. Rep. 2014, 4, 1-5. [CrossRef]

40. Bassi, D.; Iryu, Y.; Braga, J.C.; Takayanagi, H.; Tsuji, Y. Bathymetric distribution of ichnocoenoses from recent subtropical algal nodules off Fraser Island, eastern Australia. Palaeogeogr. Palaeoclimatol. Palaeoecol. 2013, 369, 58-66. [CrossRef]

41. Basso, D.; Nalin, R.; Nelson, C.S. Shallow-Water Sporolithon Rhodoliths From North Island (New Zealand). Palaios 2009, 24, 92-103. [CrossRef]

42. Leal, R.N.; Bassi, D.; Posenato, R.; Amado-Filho, G.M. Tomographic Analysis for Bioerosion Signatures in Shallow-Water Rhodoliths from the Abrolhos Bank, Brazil. J. Coast. Res. 2012, 279, 306-309. [CrossRef] 